\title{
Effects of Carbon Nanotube-Phosphorus Based Flame Retardant Combinations on Flammability of Polypropylene
}

\author{
Karbon Nanotüp-Fosfor Esaslı Güç Tutuşur Kombinasyonlarının Polipropilenin Güç Tutuşur \\ Özelliğine Etkisi
}

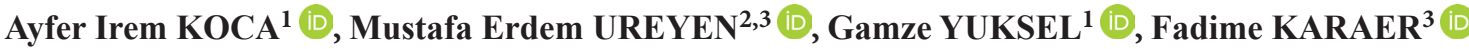 \\ ${ }^{1}$ Eskisehir Technical University, Department of Advanced Technologies, 26555, Eskisehir, Turkey \\ ${ }^{2}$ Eskisehir Technical University, Fashion and Textile Design Department, 26470, Eskisehir, Turkey \\ ${ }^{3}$ Eskisehir Technical University, Environmental Engineering Department, 26555, Eskisehir, Turkey
}

\begin{abstract}
The effects of multi-walled carbon nanotubes (MWCNTs) on fire behavior of phosphorus-based flame retardant (PBFR)/polypropylene (PP) were investigated. Two different type phosphorus-based flame retardant that commercially available; ammonium polyphosphate-based (Exolit AP 760) and organic phosphorous-based (Aflammit PCO 900) powders were studied to enhance the flammability of polypropylene. Phosphorus-based flame retardant content was fixed at $8 \mathrm{wt} \%$ of total flame retardant (FR) formulation. MWCNTs was incorporated into FR formulation at four different concentrations $(0.5 \mathrm{wt} \%, 1.0 \mathrm{wt} \%, 1.5 \mathrm{wt} \%$ and $2.0 \mathrm{wt} \%)$. All composites were prepared by melt compounding in a twin-screw extruder followed by injection molding technique. Thermal properties and flammability of the prepared samples were determined by thermogravimetric analysis (TGA), limiting oxygen index (LOI) and micro combustion calorimetry (MCC). Incorporation of organic phosphorous-based powder into PP matrix showed a better fire performance compared to ammonium polyphosphate-based flame retardant by resulting in an $11.6 \%$ higher LOI value. The LOI values decreased with the incorporation of MWCNTs into PP/ PBFR combinations; however, they still increased the thermal stability of each respective system. The addition of $2.0 \mathrm{wt} \% \mathrm{MWCNTs}$ decreased the LOI value of PP/organic phosphorous-based FR system 5.2\% higher than PP/ammonium polyphosphate-based FR system. The heat release rate of PP reduced in the presence of both PBFRs, but; increased with the introduction of MWCNTs.
\end{abstract}

Keywords: Technical Textile, Flame Retardant, Polypropylene, Carbon Nanotube, Micro Combustion Calorimetry.

$\ddot{O} z$

Bu çalışmada çok duvarlı karbon nanotüplerin (MWCNT), fosfor esaslı güç tutuşur katkılı polipropilenin yanma davranışı üzerindeki etkileri araştırılmıştır. Ticari olarak temin edilebilen iki farklı tipteki fosfor esaslı güç tutuşur katkı, amonyum polifosfat esaslı Exolit AP 760 ve organik fosfor esaslı Aflammit PCO 900, polipropilenin güç tutuşur özelliğinin iyileştirilmesi amacıyla kullanılmıştır. Fosfor esaslı güç tutuşur katkı oranı, bütün güç tutuşur formülasyonlarında \%8 oranında sabit tutulmuştur. Çok duvarlı karbon nanotüpler dört farklı oranda $(\% 0,5, \% 1,0, \% 1,5$ ve \%2,0) güç tutuşur kompozisyonlara eklenmiştir. Bütün kompozitler çift vidalı ekstrüderde polimere katılmış, sonrasında enjeksiyon kalıplama tekniği kullanılarak kalıplanmıştır. Hazırlanan kompozitlerin termal özellikleri ve güç tutuşur özellikleri termogravimetrik analiz (TGA), limit oksijen indeksi (LOI) ve mikro yanma kalorimetresi (MCC) kullanılarak belirlenmiştir. Organik fosfor içeren güç tutuşur katkısı, amonyum polifosfat içeren güç tutuşur katkısına göre \%11,6 oranında daha yüksek bir LOI değeri ile daha iyi bir güç tutuşur performans göstermiştir. Çok duvarlı karbon nanotüplerin ilavesi, polipropilen/fosfor esaslı güç tutuşur kombinasyonlarının LOI değerlerini düşürse de bütün sistemlerin termal stabilitesini yükseltmiştir. \%2 oranında çok duvarlı karbon nanotüp ilavesinin polipropilen/organik fosfor esaslı kompozitin LOI değerini polipropilen/amonyum polifosfat esaslı kompozite göre \%5,2 oranında daha fazla düşürdüğü görülmüştür. Her iki fosfor esaslı güç tutuşur varlığında polipropilenin 1sı salınım hızı azalmıştır; ancak çok duvarlı karbon nanotüp ilavesi ile tekrar artmıştır.

Anahtar kelimeler: Teknik Tekstil, Güç Tutuşur, Polipropilen, Karbon Nanotüp, Mikro Yanma Kalorimetresi. 


\section{INTRODUCTION}

Flame retardant polypropylene (PP) fibre is widely used in textile industry and related fields such as transportation, electric wire and cable, and decorative materials, due to its good processing performance, excellent chemical and thermal resistance in addition to its low cost [1]. PP burns rapidly without leaving a char residue due to its fully aliphatic carbon structure [2]. Phosphorous based flame retardant additives for PP have gain importance for more than 30 years after realizing the health and environmental impact of halogenated compounds because of toxic gas and smoke formation [3]. However, high levels of loading of phosphorous-based flame retardant additives are generally needed to achieve a reasonable flame retardancy which limits the applicability of polypropylene in some fields like fibre spinning [4]. By incorporating synergist additives into the system, the concentration of phosphorous based flame retardant (PBFR) additives can be reduced.

Carbon nanotubes (CNTs) are highly flame resistant and thermally anisotropic. They can be a good candidate as a synergist for the PP/PBFR combination. Low loading rate of CNTs $(<3 \mathrm{wt} \%)$ has been reported to enhance the flame-retardant properties of different polymers [5-8]. CNTs are fascinated class of nanoparticles which act as a carbon source, forming a heat shield over the polymer layer. It has the protective layer with a continuous network structure that promotes the flame retardancy of the polymer composites. Kashiwagi et al. [9] revealed that multi-walled carbon nanotubes (MWCNTs) enhance the thermal stability of PP and significantly reduce the heat release rate of PP. On the other hand, Shahvazian and Seyedmir [10] found that MWCNTs interfere with thermal stabilization and flame retardation efficiency of both APP/PER and red phosphorus flame retardant systems in the PP.

The class of phosphorus-based flame retardants includes a broad range of inorganic and organic compounds, including phosphates, phosphonates, phosphinates, phosphine oxides, phosphates and red phosphorus [6]. In this work, two different types of PBFR were chosen to investigate their effects on the flammability of polypropylene in the presence/ absence of CNTs; an inorganic PBFR (ammonium polyphosphate, Exolit AP 760) and an organic PBFR (cyclic phosphonate, Aflammit PCO 900). All samples were blended in twin screw micro compounder and injection moulded. Thermal properties and flammability of the prepared samples were determined by thermogravimetric analysis (TGA), limiting oxygen index (LOI) and micro combustion calorimetry (MCC).

\section{EXPERIMENTAL SET-UP AND PROCEDURE}

\subsection{Materials}

APP-based IFR (Exolit AP 760, industrial) was obtained from Clariant Plastics and Coatings AG, Germany. Cyclic phosphonate (Aflammit PCO 900, industrial) was supplied by Thor $\mathrm{GmbH}$, Germany. Isotactic polypropylene with a melt flow index (MFI) of $35 \mathrm{~g} / 10 \mathrm{~min}\left(230^{\circ} \mathrm{C}, 2.16 \mathrm{~kg}\right)$ was used. Multi-walled carbon nanotubes (MWNTs) (Purity: $>95 \%$, specific surface area: $>200 \mathrm{~m}^{2} / \mathrm{g}$, average diameter of $10-20 \mathrm{~nm}$, and length of $0.5-2 \mu \mathrm{m}$ ) were purchased from Grafen Co., Turkey. All the materials were used directly without further purification. APP-based IFR (Exolit AP 760) and cyclic phosphonate (Aflammit PCO 900) were represented by FR1 and FR2, respectively, within the entire text.

\subsection{Methods}

Reference PP and phosphorus-based flame retardants (PBFRs) were dried in a vacuum oven at $65{ }^{\circ} \mathrm{C}$ for $3 \mathrm{~h}$ before use and were mixed in the presence/absence of CNTs by using a mechanical mixer before processing. Samples were compounded by a twin-screw micro compounder operated at $180^{\circ} \mathrm{C}$ and moulded by injection (DSM Xplore, The Netherlands). The total content of phosphorus-based FR was kept constant $(8 \mathrm{wt} \%)$ in the formulations. The loading of CNTs was differed from $0.5 \mathrm{wt} \%$ to $2.0 \mathrm{wt} \%$ to investigate its effect on the flammability of PP/PBFR composites (Table 1). The maximum loading of PBFRs and CNTs were held constant at $10 \mathrm{wt} \%$. This maximum value was presumed to be an upper limit to consider their potential use for polypropylene fibre spinning [4].

Table 1. Sample compositions with respective LOI values

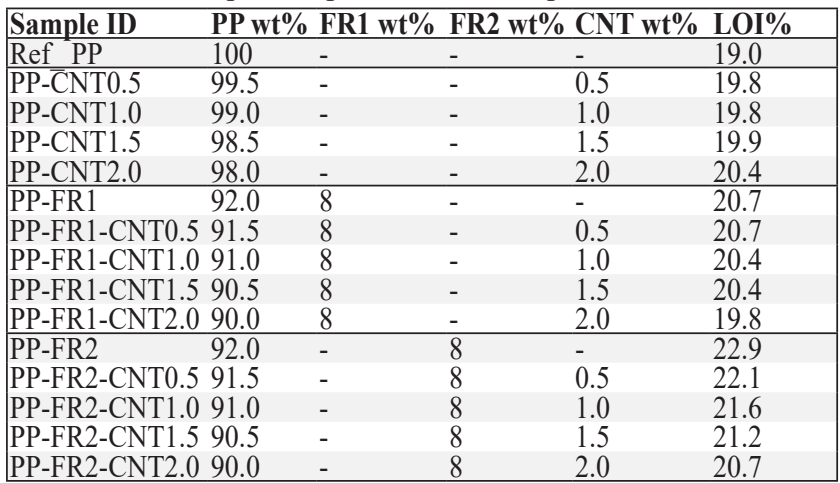

\section{ANALYSIS}

The limiting oxygen index (LOI) values were measured by LOI test device (Concept Equipment, United Kingdom) according to ASTM D 2863. 
Thermal analyses were carried out on a thermal analyser (Q600 SDT, TA Instruments, USA). Samples of $10 \pm 0.1 \mathrm{mg}$ were heated in alumina pans from room temperature to 800 ${ }^{\circ} \mathrm{C}$ at a heating rate of $10{ }^{\circ} \mathrm{C} / \mathrm{min}$ under nitrogen flow.

The micro-combustion calorimeter (MCC) tests were conducted according to ASTM D7309-2007 (Method A) using a micro calorimeter (FAA Micro Calorimeter, Fire Testing Technology, UK). About $3 \mathrm{mg}$ sample was heated from $150{ }^{\circ} \mathrm{C}$ to $750{ }^{\circ} \mathrm{C}$ using a heating rate of $1{ }^{\circ} \mathrm{C} / \mathrm{s}$ in a continuous stream of nitrogen flow $\left(80 \mathrm{~cm}^{3} / \mathrm{min}\right)$. The thermal decomposition products (also called "fuel gases") were mixed with the stream of oxygen $\left(20 \mathrm{~cm}^{3} / \mathrm{min}\right)$ before entering a $900{ }^{\circ} \mathrm{C}$ combustion furnace to calculate the data that were determined by oxygen consumption.

\section{RESULTS AND DISCUSSIONS}

\subsection{Limiting Oxygen Index (LOI) Test}

The LOI value of reference PP (19\%) increased to $19.8 \%$ by the addition of only a small amount of CNTs $(0.5 \mathrm{wt} \%)$. Incorporating more CNTs did not further increase the LOI up to the addition of $2 \mathrm{wt} \%$ which improved the LOI to $20.4 \%$. When $8 \mathrm{wt} \%$ of ammonium polyphosphate-based and organic phosphorous-based FRs were introduced in the PP matrix, LOI value of reference PP increased to $20.7 \%$ and $22.9 \%$, respectively (Table 1). Incorporation of $0.5 \mathrm{wt} \%$ CNTs did not alter the LOI value of PP/FR1 blend. The addition of $1.0 \mathrm{wt} \%$ CNTs to this system resulted in a slight decrease in LOI value. When 1.5 wt $\%$ CNTs was introduced, the LOI value remained constant; however, further decreased by the addition of
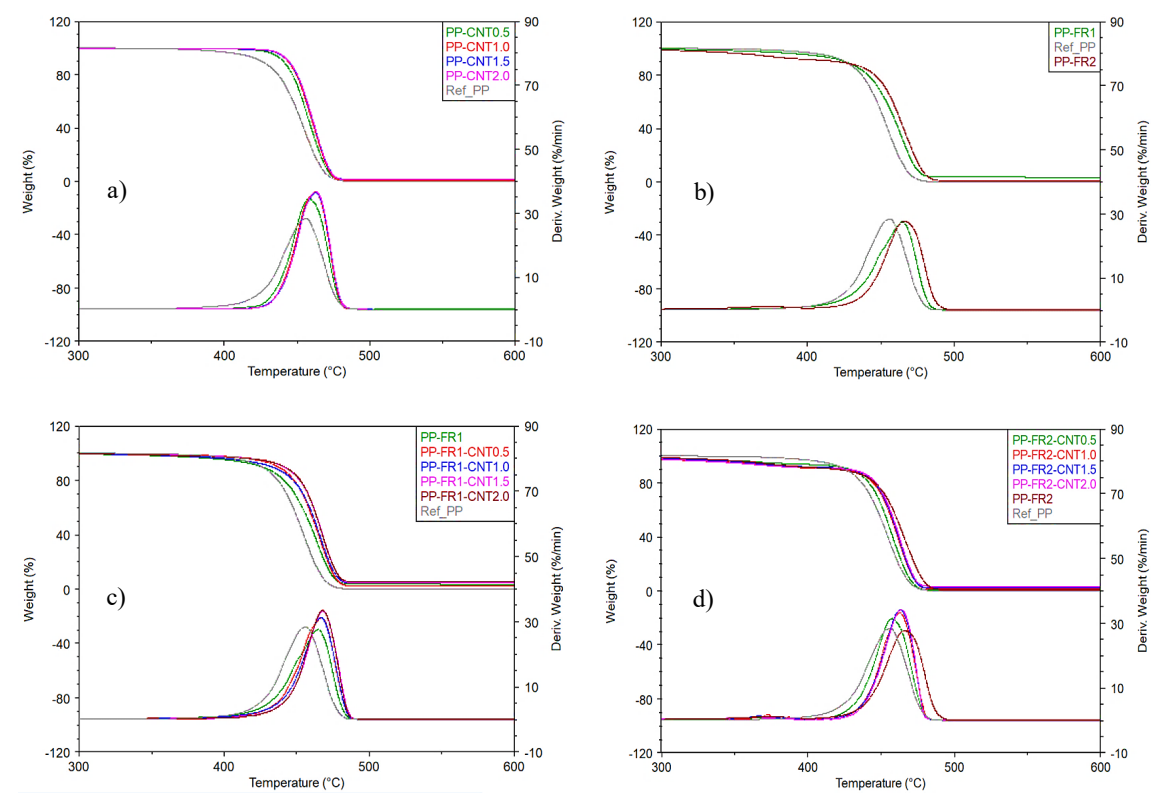
nic phosphorous-based FRs, respectively.

\subsection{Thermogravimetric Analysis (TGA)} of the maximum weight loss rate.

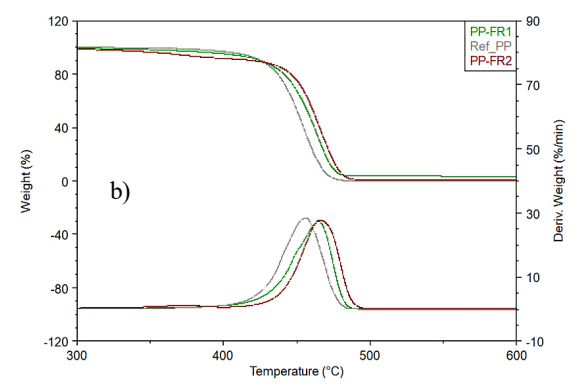

$2.0 \mathrm{wt} \% \mathrm{CNTs}$. For the PP/FR2 system, the addition of CNTs reduced the LOI down even in small amounts $(0.5 \mathrm{wt} \%)$. The higher amount of CNTs was incorporated the more reduction of LOI was concluded. Adding $2.0 \mathrm{wt} \% \mathrm{CNTs}$ into PP/PBFR system decreased the LOI value by $4.4 \%$ and $9.6 \%$ for samples extruded with ammonium polyphosphate-based and orga-

TG and DTG curves of all investigated systems are shown in Figure 1. The detailed thermal decomposition temperatures are shown in Table 2. $\mathrm{T}_{\max }$ is defined as the temperature

TGA curves revealed that a single stage decomposition had occurred for PP/CNT (Figure 1a) and PP/FR1/CNT (Figure 1c) samples initiated above $350{ }^{\circ} \mathrm{C}$. For the PP/FR2 system, all flame-retardant formulations showed a two-step decomposition process that starts at around $250{ }^{\circ} \mathrm{C}$ and 389 ${ }^{\circ} \mathrm{C}$ for first and second steps, respectively (Figure 1d). Reference PP showed a maximum of weight loss at $454.6{ }^{\circ} \mathrm{C}$.

For the PP/FR1 system, the onset temperature did not alter compared to reference PP. The addition of ammonium polyphosphate (FR1) to PP did not result in a change of the maximum mass loss rate, however, $\mathrm{T}_{\max }$ increased from $454.6^{\circ} \mathrm{C}$ to $463.3{ }^{\circ} \mathrm{C}$. The maximum mass loss rate resulted in a gradual rise with an increase of CNTs loading, exhibiting a higher $\mathrm{T}_{\text {max }}$. Incorporation of CNTs to this system shifted the mass loss temperatures at $10 \mathrm{wt} \%$ and $50 \mathrm{wt} \%$ towards higher temperatures when the amount of CNTs in the PP matrix was increased. The

Figure 1. TG and DTG curves of a) PP/CNT, b) PP/FR1-FR2, c) PP/FR1/CNT and d) PP/FR2/CNT systems 
residual masses at $500{ }^{\circ} \mathrm{C}$ and $700{ }^{\circ} \mathrm{C}$ were also increased with the addition of CNTs to this system (Table 2).

For the PP/FR2 system, the onset temperature shifted $17.5^{\circ} \mathrm{C}$ lower compared to reference PP. $\mathrm{T}_{\max }$ of reference PP increased from $454.6^{\circ} \mathrm{C}$ to $456.4{ }^{\circ} \mathrm{C}$ by the addition of organic phosphorous compound (FR2), remaining the maximum mass loss rate almost intact. After the corporation of increased loading of CNTs, both the maximum mass loss rate and $\mathrm{T}_{\max }$ of these samples were increased correspondingly. Similar to PP/FR1 system, decomposition temperatures at $10 \mathrm{wt} \%$ and $50 \mathrm{wt} \%$ shifted towards higher temperatures by the incorporation of an increased amount of CNTs. Residue formation at $500{ }^{\circ} \mathrm{C}$ and $700{ }^{\circ} \mathrm{C}$ increased from the addition of CNTs (Table 2).

Table 2. TGA data of the samples under nitrogen

\begin{tabular}{|llllll|}
\hline Sample ID & $\mathbf{T}_{10 \%}$ & $\mathbf{T}_{50 \%}$ & $\mathbf{T}_{\max }$ & $\begin{array}{l}\text { Residue } \\
\mathbf{5 0 0} \mathbf{C} \mathbf{( \% )}\end{array}$ & $\begin{array}{l}\text { Residue } \\
\mathbf{7 0 0}^{\circ} \mathbf{C} \mathbf{( \% )}\end{array}$ \\
\hline Ref PP & 425.8 & 451.2 & 454.6 & 0.26 & 0.22 \\
\hline PP-CNT0.5 & 440.6 & 456.0 & 456.7 & 1.00 & 0.84 \\
PP-CNT1.0 & 443.9 & 459.2 & 463.4 & 1.04 & 0.96 \\
PP-CNT1.5 & 444.2 & 459.8 & 463.5 & 1.33 & 1.25 \\
PP-CNT2.0 & 444.4 & 459.9 & 463.6 & 1.61 & 1.56 \\
\hline PP-FR1 & 425.8 & 458.2 & 463.3 & 3.61 & 2.61 \\
PP-FR1-CNT0.5 & 432.6 & 461.7 & 465.4 & 3.71 & 3.10 \\
PP-FR1-CNT1.0 & 437.1 & 462.5 & 466.6 & 4.67 & 4.30 \\
PP-FR1-CNT1.5 & 440.9 & 464.7 & 467.9 & 4.81 & 4.37 \\
PP-FR1-CNT2.0 & 441.4 & 464.8 & 468.1 & 5.48 & 5.09 \\
\hline PP-FR2 & 408.2 & 454.0 & 456.4 & 0.29 & 0.16 \\
PP-FR2-CNT0.5 & 428.3 & 454.9 & 457.5 & 0.56 & 0.49 \\
PP-FR2-CNT1.0 & 422.0 & 458.3 & 462.5 & 1.58 & 1.47 \\
PP-FR2-CNT1.5 & 428.6 & 458.9 & 463.1 & 2.10 & 1.97 \\
PP-FR2-CNT2.0 & 428.3 & 459.5 & 463.6 & 3.26 & 3.19 \\
\hline
\end{tabular}

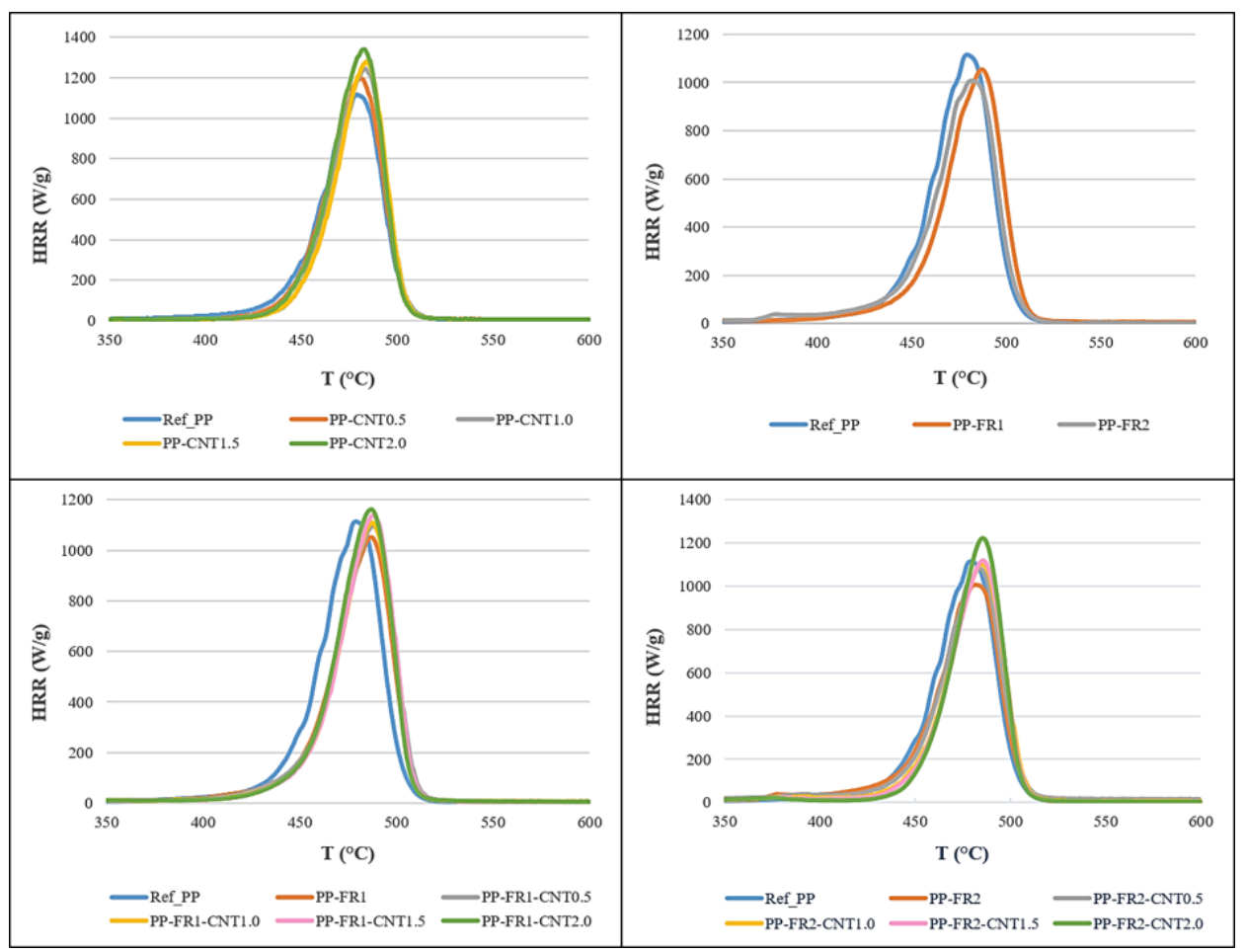

Figure 2. Heat release rate (HRR) curves over temperature for a) PP/CNT, b) PP/FR1-FR2, c) PP/FR1/CNT and d) PP/FR2/CNT systems

\subsection{Micro Combustion Calorimetry (MCC) Test}

MCC was utilized to assess the flammability of reference PP and its PBFR composites in the presence/absence of CNTs. The HRR versus temperature curves are depicted in Figure 2 and the corresponding heat release parameters are listed in Table 3. HRR is the most important parameter in characterizing combustion behaviours, evaluating and predicting fire hazards of flammable materials [11]. PHRR refers to the highest rate of heat release that a flammable material can produce. The higher the PHRR is, the more destruction a flammable material will cause under fire scenario.

PP is a highly flammable material with a peak heat release rate (PHRR) of $1134.7 \mathrm{~W} / \mathrm{g}$, heat release capacity (HRC) of $1164.0 \mathrm{~J} /(\mathrm{gK})$, total heat release (THR) of $43.9 \mathrm{~kJ} / \mathrm{g}$ and temperature at PHRR $\left(\mathrm{T}_{\mathrm{PHRR}}\right)$ of $478.4{ }^{\circ} \mathrm{C}$. With the addition of FR1 in PP matrix, the PHRR decreased significantly from 1134.7 to $1078.5 \mathrm{~W} / \mathrm{g}$ (5.0\% reduction); and HRC decreased from 1164.0 to $1102.0 \mathrm{~J} /(\mathrm{gK})$. When FR2 was introduced to PP matrix, the PHRR decreased significantly from 1134.7 to $1023.7 \mathrm{~W} / \mathrm{g}$ (9.8\% reduction); and HRC decreased from 1164.0 to $1045.0 \mathrm{~J} /(\mathrm{gK})$. The reduction of HRR and HRC could be attributed to a barrier effect formed by the FR additives which protects the PP composite by forming a char layer during combustion [12]. However, incorporation of both PBFRs caused an increase of $\mathrm{T}_{\text {PHRR }}$, from $478.4^{\circ} \mathrm{C}$ to 486.8 and $483.6{ }^{\circ} \mathrm{C}$ for FR1 and FR2, respectively. 
When introduced small amounts of CNTs such as 0.5 $\mathrm{wt} \%$ in FR formulation; PHRR, HRC and $\mathrm{T}_{\mathrm{PHRR}}$ values of both reference PP and PP/PBFR systems increased. The more loading of CNTs lead to a considerable rise in those values, nevertheless, resulted in a clear decrease of THR. One exemption to this tendency occurred by the addition of 2.0 $\mathrm{wt} \%$ CNTs; THR values of all FR systems increased then.

Table 3. MCC data of the samples

\begin{tabular}{|lllll|}
\hline Sample ID & HRC (J/(g K)) & PHRR $(\mathbf{W} / \mathbf{g})$ & THR $(\mathbf{k J} / \mathbf{g})$ & $\mathbf{T}_{\text {рнRR }}\left({ }^{\circ} \mathbf{C}\right)$ \\
\hline Ref_PP & 1164.0 & 1134.7 & 43.9 & 478.4 \\
\hline PP-CNT0.5 & 1227.2 & 1202.5 & 42.8 & 482.3 \\
PP-CNT1.0 & 1276.0 & 1249.8 & 42.3 & 484.7 \\
PP-CNT1.5 & 1279.0 & 1257.8 & 40.5 & 485.1 \\
PP-CNT2.0 & 1328.3 & 1302.2 & 43.2 & 483.8 \\
\hline PP-FR1 & 1102.0 & 1078.5 & 40.8 & 486.8 \\
PP-FR1-CNT0.5 & 1102.2 & 1090.0 & 40.7 & 488.5 \\
PP-FR1-CNT1.0 & 1147.8 & 1120.2 & 39.9 & 488.6 \\
PP-FR1-CNT1.5 & 1157.2 & 1128.8 & 39.8 & 489.7 \\
PP-FR1-CNT2.0 & 1169.7 & 1136.7 & 40.0 & 488.7 \\
\hline PP-FR2 & 1045.0 & 1023.7 & 41.0 & 483.6 \\
PP-FR2-CNT0.5 & 1128.0 & 1108.8 & 40.7 & 482.3 \\
PP-FR2-CNT1.0 & 1129.0 & 1112.2 & 40.2 & 485.8 \\
PP-FR2-CNT1.5 & 1131.0 & 1115.0 & 40.0 & 486.4 \\
PP-FR2-CNT2.0 & 1179.8 & 1150.5 & 40.6 & 485.4 \\
\hline
\end{tabular}

\section{CONCLUSIONS}

Incorporation of organic phosphorous-based flame retardant into PP matrix showed a better fire performance compared to ammonium polyphosphate-based FR by resulting $11.6 \%$ higher LOI value. When CNTs added to both PP/phosphorus-based flame retardant system, the antagonistic effect was found and LOI of these systems ( $8 \mathrm{wt} \%)$ were decreased. Only the LOI value of PP/ammonium polyphosphate-based FR system remained constant when $0.5 \mathrm{wt} \%$ CNTs incorporated. The addition of $2.0 \mathrm{wt} \%$ CNTs decreased the LOI value of PP/organic phosphorous-based FR system 5.2\% higher than PP/ammonium polyphosphate-based FR system.

The addition of the PBFR additives increased the onset temperature of decomposition compared to reference PP. The residual mass of samples was also increased with the content of the PBFR additives; however, the addition of ammonium polyphosphate-based FR resulted in more residue after burning compared to organic phosphorous-based FR.

The addition of CNTs to reference PP and PP/FR1 systems changed the onset temperature of decomposition substantially. However, it showed only a slight increase in the onset temperature of PP/FR2 system. The mass loss temperatures at $50 \mathrm{wt} \%$ also increased by the addition of CNTs to both reference PP and PP/PBFR systems. The residual masses at $500{ }^{\circ} \mathrm{C}$ and $700{ }^{\circ} \mathrm{C}$ were also increased with the addition of CNTs for all systems.

Incorporation of FR2 to PP decreased the PHRR values of reference PP two times higher than FR1. Further addition of CNTs to all systems concluded an increase of PHRR. Temperature of peak heat release rate increased also for all loading of additives. THR values of all samples declined except the ones extruded with $2.0 \mathrm{wt} \%$ CNTs.

\section{Acknowledgments}

This study was supported by Eskişehir Technical University Scientific Research Projects Commission under grant no. 1404E292.

\section{References}

[1] Du, B., Guo, Z., \& Fang, Z. (2009). Effects of organo-clay and sodium dodecyl sulfonate intercalated layered double hydroxide on thermal and flame behaviour of intumescent flame retarded polypropylene. Polymer Degradation and Stability, 94(11), 1979-1985.

[2] Zhang, S., \& Horrocks, A. R. (2003). A review of flame retardant polypropylene fibres. Progress in Polymer Science, 28(11), 1517-1538.

[3] Antoš, K., \& Sedlář, J. (2005). Influence of brominated flame retardant thermal decomposition products on HALS. Polymer Degradation and Stability, 90(1), 188-194.

[4] Horrocks, A. R. (2011). Flame retardant challenges for textiles and fibres: new chemistry versus innovatory solutions. Polymer Degradation and Stability, 96(3), 377-392.

[5] Kim, Y. S., \& Davis, R. (2014). Multi-walled carbon nanotube layer-by-layer coatings with a trilayer structure to reduce foam flammability. Thin Solid Films, 550, 184-189.

[6] Laoutid, F., Bonnaud, L., Alexandre, M., Lopez-Cuesta, J.-M., \& Dubois, P. (2009). New prospects in flame retardant polymer materials: from fundamentals to nanocomposites. Materials Science and Engineering: R: Reports, 63(3), 100-125.

[7] Liang, S., Neisius, N. M., \& Gaan, S. (2013). Recent developments in flame retardant polymeric coatings. Progress in Organic Coatings, 76(11), 1642-1665.

[8] Yin, X., Krifa, M., \& Koo, J. H. (2015). Flame-Retardant Polyamide 6/Carbon Nanotube Nanofibers: Processing and Characterization. Journal of Engineered Fabrics \& Fibers (JEFF), 10(3).

[9] Kashiwagi, T., Grulke, E., Hilding, J., Harris, R., Awad, W., \& Douglas, J. (2002). Thermal degradation and flammability properties of poly (propylene)/carbon nanotube composites. Macromolecular rapid communications, 23(13), 761-765.

[10] Shahvazian, M., \& Seyedmir, M. R. (2012). Effects of MWNTs on Flame Retardation and Thermal Stabilization Performance of Phosphorus-containing Flame Retardants in Polypropylene. Orient. J. Chem., 28, 1631-1637. 
[11] Babrauskas, V., \& Peacock, R. D. (1992). Heat release rate: the single most important variable in fire hazard. Fire safety journal, 18(3), 255-272.
[12] Rabe, S., Chuenban, Y., \& Schartel, B. (2017). Exploring the modes of action of phosphorus-based flame retardants in polymeric systems. Materials, 10(5), 455. 